\title{
Et registrert behov
}

I dette nummer av Tidsskriftet etterlyses et kvalitetsregister for barn og unge med synshemning, slik alle andre nordiske land har (1). Det finnes i dag to nasjonale registre som omfatter barn som kan ha synsvansker: Norsk nyfødtmedisinsk kvalitetsregister (2), der man registrerer behandling av nyfødte innlagt i sykehus, og Cerebral pareseregisteret i Norge (3). Ingen av disse inneholder imidlertid informasjon om barnas synsfunksjon.

Et helseregister er en strukturert samling av informasjon knyttet til enkeltindivider om deres helsetilstand, organisert slik at man lett kan kombinere opplysninger. Man skiller mellom to typer registre: sentrale helseregistre og medisinske kvalitetsregistre (4). Slike nasjonale helseregistre er blant våre viktigste redskaper for å evaluere behandling og fremme helsetiltak i befolkningen. Det er som oftest de samme spørsmålene man ønsker å få svar på: Får alle hjelp? Hvilken hjelp er best? Er hjelpen like god overalt?

Det er et omfattende arbeid som må utføres før et register er oppe og i drift. Et godt register fordrer godt samarbeid mellom ulike fagmiljøer. Når dataene skal analyseres, kan man fort komme opp i delikate situasjoner, for eksempel når ulik praksis i forskjellige fagmiljøer skal sammenlignes og ulike regioner vurderes mot hverandre.

I en artikkel basert på en undersøkelse fra Kreftregisteret, publisert for en tid tilbake, kunne resultatene tyde på at utdanning og inntekt avgjør hvilken behandling som tilbys (5). Reaksjonene lot ikke vente på seg (6). En spesialist innen fagområdet mente at bildet som ble tegnet ble for enkelt, da viktige variabler var utelatt (7). Forskernes resultater ble imidlertid hengende i luften, og det kan være vanskelig å ha sikre formeninger om hva som er riktig (8). Man kan $i$ alle fall være enige om viktigheten av at registre inneholder alle relevante variabler, og at variablene kanskje må endres med tiden.

Nabolandene våre er kommet langt i utvikling og bruk av data fra helseregistre. Mange av resultatene derfra kan vi også benytte i Norge, da befolkningene er nokså like. Men når det gjelder kvalitetssikring av egen praksis, nytter det ikke å tyvkikke over grensen. Vi må ha egne tall for å kunne gjøre egne sammenligninger og slik sikre at helsetilbudet blir likeverdig og forutsigbart $\mathrm{i}$ hele landet.

Hva med Blindekartoteket? Det norske blindekartotek ble opprettet i 1968. Det var et av de aller tidligste helseregistrene i landet og inkluderte både barn og voksne med synshemning. Men registeret ble nedlagt i midten av 1990-årene på grunn av økte krav til datasikkerhet og personvern samt sviktende registrering. De siste 20 år har fagmiljøet flere ganger anbefalt gjenopprettelse av et register over barn og unge med synshemning. En samlet oversikt er vesentlig både for å finne årsak til øyelidelser, for riktig fordeling av ressurser og for å sikre at synshemmede får det tilbudet de har krav på. Et register kan her være med på å fange opp pasienter med uavklart diagnose.

Behovet for å få stilt riktig diagnose har alltid vært viktig, og behovet vil ikke bli mindre i tiden som kommer. Med mulighet for nye behandlingsmetoder, som genterapi når en genfeil i arvemassen gir sykdom, blir detaljert utredning og diagnostikk helt essensielt. Den første genterapien for arvelige netthinnesykdommer ligger antagelig ikke langt frem i tid. En av de vanligste er retinitis pigmentosa, som gir alvorlig nedsatt syn hos barn og yngre voksne. En form for kartlegging og registrering av denne pasientgruppen vil være svært nyttig.

Barn og unge er i utgangspunktet ingen sterk pasientgruppe. Barn med nedsatt syn har ofte andre funksjonsvansker i tillegg til synsnedsettelsen og trenger noen til å tale deres sak. På dette området utfører Norges Blindeforbund et omfattende og svært viktig arbeid. Tilbud om samlinger, kurs og leire betyr mye for familier med barn og ungdom med synshemning.

Punktprevalensstudien fra fagmiljøet ved øyeavdelingen ved Haukeland universitetssykehus i dette nummer av Tidsskriftet (1) er et annet prisverdig initiativ. Studien gir et bilde av barna, deres behov og hvilke utfordringer det norske helsevesenet står overfor. Prosessen med å fremskaffe data er interessant lesning. Gruppen har lagt ned et omfattende arbeid med å kartlegge situasjonen her til lands. Til tross for arbeidsinnsatsen antyder forfatterne at de kanskje bare fant halvparten av de barna man forventet har en synshemning, dette ut fra lignende undersøkelser i andre skandinaviske land. For å fange opp alle barn med synshemning og fremme et likeverdig og forutsigbart helsetilbud er det behov for et landsdekkende helseregister. Det bør opprettes i nær fremtid.

\section{Dordi Austeng}

dordi.austeng@ntnu.no

Dordi Austeng (f. 1968) er spesialist i øyesykdommer og forsker med spesialkompetanse innen netthinnesykdommer. Hun er overlege ved Øyeavdelingen ved St. Olavs hospital og postdoktor ved Institutt for nevromedisin, Norges teknisk-naturvitenskapelige universitet.

Forfatter har fylt ut ICMJE-skjemaet og oppgir ingen interessekonflikter.

\section{Litteratur}

1. Haugen $\mathrm{OH}$, Bredrup C, Rødahl E. Nedsatt syn hos barn og unge i Norge. Tidsskr Nor Legeforen 2016; 136: 996-1000.

2. Norsk nyfødtmedisinsk kvalitetsregister. www.kvalitetsregistre.no/registers/ norsk-nyfodtmedisinsk-kvalitetsregister (2.6.2016)

3. Cerebral pareseregisteret i Norge. www.kvalitetsregistre.no/registers/ cerebral-pareseregisteret-i-norge (2.6.2016).

4. Nasjonalt helseregisterprosjekt. www.helseregistre.no/ (2.6.2016)

5. Nilssen $Y$, Strand TE, Fjellbirkeland $L$ et al. Lung cancer treatment is influenced by income, education, age and place of residence in a country with universal health coverage. Int J Cancer 2016: 138: 1350-60.

6. Dommerud T. De rikeste kreftpasientene får oftest operasjon. Aftenposten 2.5.2016.

7. Wahba A. Klasseskille i kreftbehandlingen? Datagrunnlaget er altfor svakt for slike konklusjoner. Aftenposten 5.5.2016.

8. På lederplass. Uakseptabel forskjellsbehandling i helsevesenet. Aftenposten 8.5.2016. 